\title{
Prevalence of hypovitaminosis $D$ in severely obese subjects referred to bariatric surgery
}

\author{
Prevalência de hipovitaminose $\mathrm{D}$ em obesos graves encaminhados à \\ cirurgia bariátrica
}

Nataly Azenate Palhares de Oliveira ${ }^{1}$ (D), Karine Lima Curvello Silva ${ }^{1}$ (D), Thalane Souza Santos Silva ${ }^{1}$ (D), Isis Henriques de Almeida Bastos $^{3}$ (D), Cláudia da Silva Daltro ${ }^{1,2}$ (D), Carla Hilário da Cunha Daltro ${ }^{1,2,3}$

\begin{abstract}
Study Design: Cross-sectional. Objective: Estimating the prevalence of hypovitaminosis $D$ in a group of severely obese subjects referred to bariatric surgery. Methods: This study evaluated severely obese patients aged $\geq 18$ years assisted by a specialized team in bariatric surgery. Clinical, anthropometric, and laboratory data were obtained from patient records. Plasma $25(\mathrm{OH}) \mathrm{D}$ was determined by chemiluminescence and levels $\leq 20 \mathrm{ng} / \mathrm{mL}$ was considered as Hypovitaminosis D. The data were analyzed using the Statistical Package for Social Sciences $^{\circledR}$ (SPSS) 20.0. Variables were described using descriptive statistics. For the comparison of the three groups, ANOVA, Kruskal-Wallis, and Pearson's chi-square tests were used. Spearman correlation test was performed to assess correlations between $25(\mathrm{OH}) \mathrm{D}$ and the other variables. P-values $<0.05$ were considered to be significant. Results: The study included 400 individuals, $71 \%$ were female with the mean age (SD) and BMI (SD) of 35.6 (9.1) years and $41.4(5.1) \mathrm{kg} / \mathrm{m}^{2}$, respectively. The vitamin D ranged from 4.5 to $62.4 \mathrm{ng} / \mathrm{mL}$ and the mean (SD) was 24.7 (7.9) $\mathrm{ng} / \mathrm{mL}$. In this sample, $117(29.3 \%)$ individuals had hypovitaminosis $\mathrm{D}$. There was a negative correlation between $25(\mathrm{OH}) \mathrm{D}$ and BMI $(r=-0.110 ; p=0.028)$ and parathormone $(r=-0.152 ; p=0.006)$ and positive correlation with serum calcium $(r=0.132 ; p=0.013)$ and phosphorus $(r=0.116 ; p=0.027)$. Conclusion: Severely obese subjects had a high prevalence of hypovitaminosis $D$ even living in a sunny state.
\end{abstract}

Keywords: Vitamin D Deficiency; Vitamin D; Obesity; Bariatric Surgery; Adult.

\section{RESUMO}

Modelo do estudo: Estudo transversal. Objetivo: estimar a prevalência da hipovitaminose D em um grupo de obesos graves encaminhados à cirurgia bariátrica. Métodos: Foram estudados obesos atendidos por uma equipe especializada em cirurgia bariátrica, com 18 anos ou mais de ambos os sexos. Dados clínicos, antropométricos e laboratoriais foram obtidos dos prontuários dos pacientes. A $25(\mathrm{OH})$ D plasmática foi determinada por quimioluminescência e valores $\leq 20 \mathrm{ng} / \mathrm{mL}$ foram considerados como hipovitaminose D. Os dados foram analisados utilizando o Statistical Package for the Social Sciences ${ }^{\circledR}$ (SPSS) 20.0. Estatística descritiva foi utilizada para apresentação das variáveis e para comparação dos três grupos foram utilizados os testes: ANOVA, Kruskal-Wallis e qui-quadrado de Pearson. Foram considerados estatisticamente significantes valores de $p<0,05$. Resultados: Foram estudados 400 pacientes, $71 \%$ do sexo feminino, com média (DP) de idade e IMC 35,6 $(9,1)$ anos e $41,4(5,1) \mathrm{kg} / \mathrm{m}^{2}$, respectivamente. A vitamina $D$ variou de 4,5 a $62,4 \mathrm{ng} / \mathrm{mL}$ com média (DP) de $24,7(7,9) \mathrm{ng} / \mathrm{mL}$. Na amostra, $117(29.3 \%)$ dos pacientes apresentaram hipovitaminose D. Houve correlação negativa entre $25(\mathrm{OH}) \mathrm{D}$ e IMC $(r=-0,110$; $p=0,028)$ e paratormônio $(r=-0,152 ; p=0,006)$ e correlação positiva com cálcio sérico $(r=0,132 ; p=0,013)$ e fósforo $(r=0,116 ; p=0,027)$. Conclusão: Os obesos graves apresentaram alta prevalência de hipovitaminose $D$, mesmo vivendo em um estado ensolarado.

Palavras-chave: Deficiência de Vitamina D; Vitamina D; Obesidade; Cirurgia Bariátrica; Adulto.

1. Escola de Nutrição, Universidade Federal da Bahia (UFBA), Salvador (BA), Brasil.

2. Núcleo de Tratamento e Cirurgia da Obesidade, Salvador (BA), Brasil.

3. Programa de Pós Graduação em Medicina e Saúde, UFBA, Salvador, (BA), Brasil.

$\square \quad$ Nataly Azenate Palhares de Oliveira. Av. Araújo Pinho, 32 - Canela. CEP: 40110-150. Salvador (BA), Brasil. natalyafanut@gmail.com Recebido em: 18/07/2019 | Aprovado em: 23/01/2020 


\section{INTRODUCTION}

Vitamin D, a pro-hormone, has an important and well-established role in the metabolism of calcium and phosphorus. Evidence suggests that its deficiency may also be associated with the development of metabolic syndrome, diabetes, and some types of cancer ${ }^{1,2}$.

Hypovitaminosis $D$ has been reported throughout the world, even in areas with a high incidence of ultraviolet radiation (UV) and in developed countries, where vitamin $D$ food fortification was implemented years ago ${ }^{2}$. A systematic review by Hilger et al. ${ }^{1}$ showed that $37.3 \%$ of the global population had levels of serum 25-hydroxyvitamin D (25-OH-D) below $50 \mathrm{nmol} / \mathrm{L}(<20 \mathrm{ng} / \mathrm{mL})$ and $6.7 \%$ below $25 \mathrm{nmol} / \mathrm{L}(<10 \mathrm{ng} / \mathrm{mL})$. Unger et al. ${ }^{3}$ found a prevalence of hypovitaminosis $D$ $(<30 \mathrm{ng} / \mathrm{mL})$ in $77.4 \%$ of healthy Brazilian adults.

However, the cutoff for determining the optimal vitamin D level is still under debate. The clinical practice committee of the European Calcified Tissue Society (ECTS) ${ }^{4}$ and Endocrine Societies $^{5}$ recommend values $>20 \mathrm{ng} / \mathrm{mL}$ for the healthy population. Brazilian medical societies in 2018 adopted this cutoff point and suggested that groups at risk such as obese patients undergoing bariatric surgery should maintain values between 30-60 ng/mL of serum vitamin $D^{6}$.

It is well recognized that skin pigmentation, use of sunscreen, air pollution, old age, and obesity are related to hypovitaminosis $\mathrm{D}^{2}$. Obese individuals tend to have low levels of 25-OH-D and it is inversely associated with Body Mass Index (BMI) and body fat percentage. The decrease in vitamin $D$ bioavailability in obesity is believed to be due to the storage (deposition) of this fat-soluble vitamin in adipose tissue. Besides, obese people use to have low sun exposure ${ }^{2,3,7}$. Obinwanne et al. ${ }^{8}$ evaluated 34 American women in pre-bariatric surgery (BMI $\geq 35.0 \mathrm{Kg} / \mathrm{m}^{2}$ ) and found hypovitaminosis $D(<25 \mathrm{ng} / \mathrm{mL})$ in $55 \%$ of them.

Considering the increasing worldwide prevalence of obesity, its association with hypovitaminosis $D$ and the possible secondary osteometabolic impact of this condition, this study aimed to estimate the prevalence of this deficiency in a group of severely obese adults referred for bariat- ric surgery, with high levels of miscegenation in a city with high solar irradiation.

\section{MATERIAL AND METHODS}

This is a cross-sectional study with severely obese subjects (BMI $\geq 35.0 \mathrm{~kg} / \mathrm{m}^{2}$ ) referred for bariatric surgery. The study was conducted in a reference center for the treatment of obesity in Salvador, Bahia, located in the tropical zone of the Brazilian northeast coast (latitude of $-12^{\circ} 58^{\prime} 16^{\prime \prime} \mathrm{S}$ ).

The sample size of 194 individuals was calculated considering that the prevalence of hypovitaminosis $D$ in obese patients submitted to bariatric surgery was $55 \%{ }^{8}$, with a precision of $7 \%$ and alpha of $5 \%$. Consecutive patients treated between 2014 and 2016 were included. Exclusion criteria were incomplete data; vitamin $D$ determination method different from chemiluminescence; use of parathormone (PTH) or other drugs that interfere with vitamin $D$ metabolism; patients with hyperparathyroidism and hepatic or renal disease.

The variable $25(\mathrm{OH})$ D was stratified into three different groups so that we could analyze the results according to different studies. Considering $\mathrm{ECTS}^{4}$, suitable values are above $20.0 \mathrm{ng} / \mathrm{mL}$ following the new position European Society of Endocrinology, vitamin $D$ limits were stratified in deficiency ( $<12.0 \mathrm{ng} / \mathrm{mL}$ ), insufficiency (from 12.0 to $20.0 \mathrm{ng} / \mathrm{mL}$ ), and sufficiency $(>20.0 \mathrm{ng} / \mathrm{mL})^{5}$. In this study, hypovitaminosis $D$ was defined by serum levels of vitamin $D \leq 20 \mathrm{ng} / \mathrm{mL}$ as recommended by the Brazilian societies.

Hypertensive and diabetic patients were those who referred by the medical diagnosis or those who were using specific medications. Demographic (age and gender), anthropometric (weight, height, and body mass index), and biochemical (serum total calcium, phosphorus, urea, creatinine, alkaline phosphatase, and PTH) variables were collected from medical reports.

The variable "use of vitamin D" was informed by the participants and defined as any use of it, alone or in association with other vitamins, independent of dose and time of use.

Data analysis was performed with the IBM SPSS Statistics software package, version 20.0 
(IBM Corporation, Armonk, NY, USA). Variables were described using descriptive statistics (mean or median and standard deviation or interquartile interval). For the comparison of the three groups, ANOVA, Kruskal-Wallis, and Pearson's chi-square tests were used according to the variable. Spearman correlation test was performed to assess correlations between $25(\mathrm{OH}) \mathrm{D}$ and the other variables. P-values $<0.05$ were considered to be significant.

The project was approved by the $\mathrm{Hu}$ man Research Ethics Committee of the Nutrition School of the Federal University of Bahia under No. 1.296.1592/2016.

\section{RESULTS}

The study included 400 individuals referred for bariatric surgery with a mean age (standard deviation) of 35.6 (9.1) years and $71 \%$ of them were female. Regarding the presence of chronic diseases, $33(8,3 \%)$ of the participants had diabetes and $147(36.8 \%)$ had arterial hypertension. BMI ranged from 35.0 to $60.3 \mathrm{~kg} / \mathrm{m}^{2}$, an average (SD) of $41.4(5.1) \mathrm{kg} / \mathrm{m}^{2}$ and $52.3 \%$ (209 individuals) were classified as grade III of obesity. Table 1 shows the demographic and clinical characteristics according to $25 \mathrm{OH}$ vitamin D serum levels.

\section{Table 1}

Clinical and demographic characteristics of 400 severely obese subjects according to $25 \mathrm{OH}$ vitamin D serum levels.

\begin{tabular}{|c|c|c|c|c|c|}
\hline \multirow[b]{2}{*}{ Characteristics } & \multicolumn{5}{|c|}{$25(\mathrm{OH})$ Vitamin $\mathrm{D}(\mathrm{ng} / \mathrm{mL})$} \\
\hline & $\begin{array}{c}\text { Total } \\
N=400\end{array}$ & $\begin{array}{c}\leq 20.0 \\
117(29.3 \%)\end{array}$ & $\begin{array}{c}20.1-29.9 \\
197(49.3 \%)\end{array}$ & $\begin{array}{c}\geq 30.0 \\
86(21.5 \%)\end{array}$ & $P$ \\
\hline Female & 400 & $86(73.5 \%)$ & $132(67.0 \%)$ & $66(76.7 \%)$ & 0.196 \\
\hline Age (years)* & 400 & $35.4(9.2)$ & $35.7(8.9)$ & $35.6(9.3)$ & 0.954 \\
\hline BMI $\left(\mathrm{Kg} / \mathrm{m}^{2}\right)^{*}$ & 400 & $41.7(5.0)$ & $41.6(5.2)$ & $40.6(5.1)$ & 0.244 \\
\hline Phosphorus (mg/dL)* & 365 & $3.6(0.5)$ & $3.7(0.6)$ & $3.8(0.6)$ & 0.111 \\
\hline Total calcium $(\mathrm{mg} / \mathrm{dL}) *$ & 359 & $9.1(0.4)$ & $9.2(0.5)$ & $9.2(0.5)$ & 0.088 \\
\hline PTH $(\mathrm{pg} / \mathrm{mL})^{+}$ & 328 & $36.9(24.8-47.7)$ & $31.3(22.9-39.8)$ & $29.5(21.4-38.5)$ & 0.013 \\
\hline Alkaline phosphatase $(\mathrm{U} / \mathrm{L})^{+}$ & 361 & $77.0(62.0-115.0)$ & $78.0(65.0-98.8)$ & $74.0(61.0-91.3)$ & 0.163 \\
\hline Creatinine $(\mathrm{mg} / \mathrm{dL})^{*}$ & 383 & $0.7(0.2)$ & $0.7(0.2)$ & $0.7(0.1)$ & 0.473 \\
\hline Urea $(\mathrm{mg} / \mathrm{dL})^{*}$ & 386 & $27.0(7.3)$ & $26.5(7.5)$ & $27.4(6.6)$ & 0.625 \\
\hline
\end{tabular}

${ }^{*}$ Data expressed as mean and standard deviation; ${ }^{\dagger}$ median and inter-quartile range; BMI, body mass index; PTH, parathyroid hormone. To calculate serum calcium, the patients with low albumin levels were excluded.

Vitamin D ranged from 4.5 to $62.4 \mathrm{ng} / \mathrm{mL}$ with an average (SD) of 24.7 (7.9) $\mathrm{ng} / \mathrm{mL}$, and $117(29.3 \%)$ had hypovitaminosis D.

There was a negative and statistically significant correlation among vitamin $D, B M I(r=-0.110$; $p=0.028)$, and PTH $(r=-0.152 ; p=0.006)$, while a positive correlation was found between serum phosphorus $(r=0.116 ; p=0.027)$ and calcium $(r=0.132 ; p=0.013)$.

\section{DISCUSSION}

This study showed a high prevalence of hypovitaminosis $D$ in this group of obese patients and a negative linear association among vitamin $D$,
BMI, and PTH, and a positive association between serum phosphorus and calcium.

Unger et al. ${ }^{3}$ evaluated 603 healthy adults with a mean age of 47.8 years and an average BMI of $27.2 \mathrm{~kg} / \mathrm{m}^{2}$, in a region of Brazil where the differences between seasons are more defined and found a prevalence of hypovitaminosis $D(<30 \mathrm{ng} /$ $\mathrm{mL}$ ) of $37.3 \%$ during the summer. This frequency, below the present study, might be justified by the difference between the BMI of the individuals since our study included only severely obese patients.

According to the International Federation for the Surgery of Obesity and Metabolic Disorders (IFSO), from 2014-2018 the patients' median BMI pre-surgery was $41.7 \mathrm{~kg} / \mathrm{m}^{2}$ (interquartile range $38.3-46.1 \mathrm{~kg} / \mathrm{m}^{2}$ ). There was wide variation betwe- 
en countries, with medians ranging from $34.2 \mathrm{~kg} / \mathrm{m}^{2}$ in South Korea to $49.1 \mathrm{~kg} / \mathrm{m}^{2}$ in Germany ${ }^{9}$.

Other researchers studied patients with severe obesity (BMI $\geq 35.0 \mathrm{~kg} / \mathrm{m}^{2}$ ) in regions with different latitudes and used similar cutoff points to $25(\mathrm{OH}) \mathrm{D}$ and found similar results. In Spain, Moizé et al. ${ }^{10}$ evaluated 231 obese individuals and found a prevalence of hypovitaminosis $D(<20 \mathrm{ng} / \mathrm{mL})$ in $67.7 \%$ of them. Aridi et al. ${ }^{11}$ showed a prevalence of hypovitaminosis D in $91.5 \%$ of patients with obesity I or II in Lebanon, and $68.9 \%$ of them had levels below $20 \mathrm{ng} / \mathrm{mL}$ of this vitamin.

It is essential to differentiate vitamin D nutritional guidelines for the general population (such as ECTS) from clinical vitamin $D$ guidelines for patient care. According to the Brazilian societies, the optimal $25(\mathrm{OH}) \mathrm{D}$ values for a healthy population (up to 60 years of age) are above $20 \mathrm{ng} / \mathrm{mL}$ and between 30 and $60 \mathrm{ng} / \mathrm{mL}$ for at-risk groups ${ }^{4,7,12,13}$.

The negative correlation between vitamin $D$ and BMI can be related to the sequestration (storage) of this fat-soluble vitamin by adipocytes, reducing its bioavailability ${ }^{1-3}$. This correlation was also observed by Moizé et al. ${ }^{10}$ $(r=-0.234 ; p<0.05)$ for females. As expected, PTH was inversely correlated with $25(\mathrm{OH}) \mathrm{D}$, whereas there was a positive correlation between this and calcium and phosphorus. It is known that as the concentration of 1.25-dihydroxyvitamin $D$ rises, the intestinal absorption and renal reabsorption of phosphorus increase. The $25(\mathrm{OH})$ $D$ deficiency leads to the serum calcium levels reduction, resulting in secondary hyperparathyroidism and inadequate mineralization or skeletal demineralization ${ }^{1,3,10}$.

A convenience sample is one of the limitations of this study, nevertheless, the patient profile is similar to those of many obesity treatment centers. Comparison with other studies is one of the limitations of this study, as there is no uniformity of vitamin $D$ normal values. This is also a limitation of other studies due to the lack of consensus on the optimal serum value of this vitamin. The vitamin $D$ dosage method was standardized to ensure the internal validity of the study, however, the dosages have not been performed in the same laboratory and we cannot guarantee that the tests belonged to the same manufacturer, which may interfere with the variability in the 25- OHD.
In conclusion, this study showed that severely obese subjects had a high prevalence of hypovitaminosis $D$ suggesting that these patients deserve greater attention by health care professionals, even in sunny countries. Considering that after bariatric surgery it is difficult to maintain adequate levels of vitamin $D$, as well as other micronutrients, it would be interesting to reach levels between 30 and $60 \mathrm{ng} / \mathrm{mL}$ already in the preoperative period.

\section{FINANCING SOURCES}

"This study was financed partly by the Coordenação de Aperfeiçoamento de Pessoal de Nível Superior Brasil (CAPES) - Finance Code 001"

\section{ACKNOWLEDGEMENTS}

We are thankful to Dr. Erivaldo Alves for allowing us to access the data on the medical reports.

\section{REFERENCES}

1. Hilger J, Friedel A, Herr R, Rausch T, Roos F, Wahl D A, et al. A systematic review of vitamin $D$ status in populations worldwide. $\mathrm{Br}$ J Nutr. 2014;111(1):23-45. DOI: https://doi.org/10.1017/S0007114513001840

2. Holick MF, Binkley NC, Bischoff-Ferrari HA, Gordon CM, Hanley DA, Heaney RP, et al. Evaluation, treatment, and prevention of vitamin $D$ deficiency: An endocrine society clinical practice guideline. J Clin Endocrinol Metab. 2011;96(7):1911-30. DOI: https://doi.org/10.1210/ jc.2011-0385

3. Unger MD, Cuppari L, Titan SM, Magalhães MCT, Sassaki $A L$, dos Reis LM, et al. Vitamin D status in a sunny country: Where has the sun gone? Clin Nutr. 2010;29(6):784-8. DOI: https://doi.org/10.1016/j.clnu.2010.06.009

4. Lips $P$, Cashman KD, Lamberg-Allardt C, Bischoff-Ferrari $H A$, Obermayer-Pietsch BR, Bianchi $M$, et al. Management of endocrine disease: Current vitamin $D$ status in European and Middle East countries and strategies to prevent vitamin $D$ deficiency; a position stateme):(nt of the European Calcified Tissue Society. Eur J Endocrinol. 2019;180(4)23-54. DOI: 10.1530/EJE-18-0736.

5. Munns CF, Shaw N, Kiely M, Specker BL, Thacher TD, Ozono K, et al. Global Consensus Recommendations on Prevention and Management of Nutritional Rickets. J Clin Endocrinol Metab. 2016;101(2):394-415. DOI: https://doi.org/10.1210/jc.2015-2175

6. Ferreira CES, Maeda SS, Batista MC, Lazaretti-Castro M, Vasconcellos LS, Madeira M, et al. Consensus - 
reference ranges of vitamin $D[25(\mathrm{OH}) \mathrm{D}]$ from the Brazilian medical societies. Brazilian Society of Clinical Pathology/Laboratory Medicine (SBPC/ML) and Brazilian Society of Endocrinology and Metabolism (SBEM). J. Bras. Patol. Med. Lab. 2017;53(6): 377-81. DOI: http://dx.doi.org/10.5935/1676-2444.20170060

7. Lespessailles E, Toumi H. Vitamin D alteration associated with obesity and bariatric surgery. Experimental Biology and Medicine. 2017;242(10):1086-1094. DOI: https://doi.org/10.1177/1535370216688567

8. Obinwanne KM, Riess KP, Kallies KJ, Mathiason MA, Manske BR, Kothari SN. Effects of laparoscopic Roux-en-Y gastric bypass on bone mineral density and markers of bone turnover. Surg Obes Relat Dis. 2014;10(6):1056-62. DOI: https://doi.org/10.1016/j.soard.2014.06.018

9. International Federation for the Surgery of Obesity and Metabolic Disorders. Fourth IFSO Global Registry Report. Dendrite Clinical Systems Ltd, 2018 [Access in 13 dec 2019]. Available in: http://www.e-dendrite.com/sites/default/files/4thIFSOSummary.pdf
10. Moizé V, Deulofeu R, Torres F, De Osaba JM, Vidal J. Nutritional intake and prevalence of nutritional deficiencies prior to surgery in a spanish morbidly obese population. Obes Surg. 2011;21(9):1382-8. DOI: https://doi. org/10.1007/s11695-011-0360-y

11. Aridi HD, Alami RS, Fouani T, Shamseddine G, Tamim H, Safadi B. Prevalence of vitamin $D$ deficiency in adults presenting for bariatric surgery in Lebanon. Surg Obes Relat Dis. 2016;12(2):405-11. DOI: http://dx.doi.org/10.1016/ j.soard.2015.09.022

12. Pilz S, Zittermann A, Trummer C, Theiler-Schwetz V, Lerchbaum E, Keppel MH, et al. Vitamin D testing and treatment: a narrative review of current evidence. Endocr Connect. 2019;8(2):R27-R43. DOI: 10.1530/EC-18-0432.

13. Holick MF, Binkley NC, Bischoff-Ferrari HA, Gordon CM, Hanley DA, Heaney RP, et al. Guidelines for Preventing and Treating Vitamin D Deficiency and Insufficiency Revisited. J Clin Endocrinol Metab. 2012;97(4):1153-8. DOI: $10.1210 /$ jc.2011-2601. 